\title{
'Blind Time' - current limitations on laser ablation multi-collector inductively coupled plasma mass spectrometry (LA-MC-ICP-MS) for ultra-transient signal isotope ratio analysis and application to individual sub-micron sized uranium particles
}

\author{
Grant Craig ${ }^{1,2}$, Matthew S. A. Horstwood ${ }^{3}$, Helen J. Reid ${ }^{1,}$ Barry L. Sharp ${ }^{1}$ \\ ${ }^{1}$ Centre for Analytical Science, Department of Chemistry, Loughborough University, Loughborough, \\ Leicestershire, LE11 3TU, UK
}

${ }^{2}$ Thermo Fisher Scientific Bremen GmbH, Hanna-Kunath Str. 11, 28359 Bremen, Germany

${ }^{3}$ NERC Isotope Geosciences Laboratory, British Geological Survey, Nicker Hill, Keyworth, Nottinghamshire, NG12 $5 G G$, UK

\begin{abstract}
The application of laser ablation multi-collector inductively coupled plasma mass spectrometry (LA-MC-ICP-MS) to the isotope ratio analysis of $\mathrm{UO}_{\mathrm{x}}$ particles has the potential to improve the isotopic determination of these particles when compared to currently utilised ICP-MS techniques. To investigate this a high-speed, integrated ablation cell and dual concentric injector design, was tested in the expectation that the resulting increase in signal to noise ratio and sample ion yield would improve the determination of ${ }^{234} \mathrm{U} /{ }^{238} \mathrm{U},{ }^{235} \mathrm{U} /{ }^{238} \mathrm{U}$ and ${ }^{236} \mathrm{U} /{ }^{238} \mathrm{U}$ for such materials. However, when compared to a slower washout, more established low-volume cell design, the highly transient signals of the new design proved challenging for the mixed detector array of the multicollector mass spectrometer, introducing a new bias. We describe this bias, referred to as 'blind time', and model its impact on $\mathrm{UO}_{\mathrm{x}}$ particle analysis. After accounting for blind time, average precisions for the uranium isotopic composition of sub-micron sized $\mathrm{UO}_{\mathrm{x}}$ particles using LA-MC-ICP-MS were $3 \% 1 \mathrm{RSD}$ for ${ }^{235} \mathrm{U} /{ }^{238} \mathrm{U}$ and $8 \% 1 \mathrm{RSD}$ for ${ }^{234} \mathrm{U} /{ }^{238} \mathrm{U}$. When ablating a glass rather than a $U O_{x}$ particle, uncertainties of $1.3 \% 1$ RSD for ${ }^{235} \mathrm{U} /{ }^{238} \mathrm{U}$ were achieved for 150nm equivalent particle sizes using LA-MC-ICP-MS.
\end{abstract}

\section{Introduction}

International governmental agencies have introduced safeguards designed to ensure the compliance of nuclear facilities (e.g. nuclear reactors, enrichment facilities or test sites) to stated declarations and to detect undeclared, unauthorised activities ${ }^{1}$. A prime concern of these safeguards are microparticles (down to a few hundred nanometres in diameter) containing perhaps only picograms of actinide material. Such actinide bearing particles are also vital to nuclear forensics ${ }^{2,3}$ (the study of intercepted nuclear material) and to environmental studies of previously contaminated locations ${ }^{4,5}$. For all three areas of interest the isotopic composition can give a wealth of information including but not limited to the sample age, intended use and place of manufacture ${ }^{3,6-}$

8. Routine inspections for safeguards analysis uses cotton swipes to collect particles which are then extracted to determine the uranium $(\mathrm{U})$ or plutonium $(\mathrm{Pu})$ isotopic composition by mass spectrometry ${ }^{9}$. Dissolution of the collected particles for analysis by inductively coupled plasma mass spectrometry (ICP-MS) is routine ${ }^{10}$, however 
the isotope ratios recovered are for the bulk of the material: analysing each particle individually could reveal a strong deviation from the bulk ${ }^{11}$. Separation and dissolution of individual $U$ particles has been successfully implemented for ICP-MS ${ }^{12-14}$, and successfully compared to secondary ion mass spectrometry (SIMS) analysis of the same material ${ }^{15}$. For routine analysis thermal ionisation mass spectrometry (TIMS) and SIMS are commonly used for uranium particles, with SIMS predominant ${ }^{1}$. However other forms of mass spectrometry, including laser ablation (LA-) ICP-MS, have been investigated as complimentary techniques.

LA-ICP-MS is a promising technique for nuclear safeguards, requiring less sample preparation than either TIMS or SIMS. The primary advantages of LA-ICP-MS are speed of analysis, more widespread instrumentation and therefore accessibility and ease of use. Over time, sample size for LA-ICP-MS has varied from pressed powder pellets ${ }^{16}$ to $10-30 \mu \mathrm{m}$ particles $s^{11,17,18}$ and smaller ${ }^{19}$. Recently the scale has shifted from the micron to submicron ${ }^{20-}$ 24 , attention being focussed by recent inter-laboratory comparisons ${ }^{25-27}$. To date, several studies have analysed micron and sub-micron uranium particles by LA-ICP-MS. Pointurier et al ${ }^{21}$ compared a $213 \mathrm{~nm}$ laser system coupled with a quadrupole-based ICP-MS, to TIMS and SIMS for ${ }^{235} \mathrm{U} /{ }^{238} \mathrm{U}$ isotope ratio analysis. Kappel et $a{ }^{22}$ analysed ${ }^{235} \mathrm{U} /{ }^{238} \mathrm{U}$ by LA-MC-ICP-MS as part of an evaluation of data handling strategies for single particles and Claverie et $\left.a\right|^{28}$ applied LA-MC-ICP-MS to micron-sized uranium particles, measuring both ${ }^{235} \mathrm{U} /{ }^{238} \mathrm{U}$ and ${ }^{234} \mathrm{U} /{ }^{238} \mathrm{U}$ to a precision of $2.0 \%$ 1RSD using a multiple Faraday configuration. Critically, the flexibility of ICP-MS allows modification of signal to noise ratios (SNR) by adapting conventional analysis approaches. Increasing the SNR improves the limit of detection and limit of quantification, important when considering the lack of material in sub-micron uranium particles. The SNR can be improved by compressing the transient signals generated into a shorter time frame. Short transient signals are challenging in ICP-MS, in terms of data acquisition and handling by both the ICP-MS instrument and the user ${ }^{29}$, requiring changes in methodology. One such change has been calculating isotope ratios from entire integrated transient signals rather than by each mass spectrometer cycle 18,30,31. Isotope ratio analysis of transient signals has already been pioneered for single shot laser ablation of larger materials $s^{30,32}$ as well as single particles. Spectral skew is a known problem for transient signal analysis with single collector ICP-MS, whereby inaccuracies are introduced due to differential delays in signal acquisition ${ }^{33}$. Adopting pseudo-simultaneous detection to overcome spectral skew with LA-ICP-TOF-MS for uranium particle analysis has been investigated, but was hampered by limitations in detector linearity and sample ion yield ${ }^{23}$. Multi-collector inductively coupled plasma mass spectrometers (MC-ICP-MS) achieves full simultaneous measurement by collecting each isotope on separate detectors as well as high ion yield (>7\%, Craig et $a)^{34}$ ) and as such should be ideally suited for highly transient signals. However, although isotopes signals are detected simultaneously on MC-ICP-MS, the isotope signals need not be output simultaneously. For Faraday cup detectors the signal output is reliant on the first order tau constant of the resistor in the associated amplifier ${ }^{35,36}$. As such, differential decay of the signal on different Faraday detectors can lead to variation in transient signal isotope ratio analysis. For highly transient signals, this can introduce bias in isotope ratio measurements e.g. ${ }^{37}$.This differential detector response is at its most extreme when comparing output signals from transient pulses recorded on mixed detector arrays (e.g. Faradays and ion counters) 
We set out to investigate the utility of LA-MC-ICP-MS for analysis of individual submicron UO $_{x}$ particles for $U$ isotope ratio determination. Given the small quantity of material to be analysed and the low abundance of ${ }^{234} U$ and ${ }^{236} \mathrm{U}$ in many samples it was hypothesised that a high detection efficiency and signal to noise ratio would be required. To this end we determined to apply an ultrafast combined ablation cell and torch injector design, the prototype $\mathrm{DCl}^{38}$, to the LA-MC-ICP-MS system. This system built on a key area of development in laser ablation cell design, "two-volume" cells, where a smaller cell is housed inside a larger casing. These cells have better flow dynamics than previous generations of 'single volume' ablation cells and are now standard issue from most manufacturers ${ }^{39}$. Ultrafast laser ablation sample introduction systems aim to reduce elemental fractionation, improve signal to noise, remove memory effects and achieve higher transport efficiency with sub-100 ms washout times ${ }^{40}$. As well as the $\mathrm{DCl}$, similar systems first described by Wang et $a l^{41}$ and van Malderen et $a l^{42}$ have become commercially available. Applications for these ultrafast laser ablation cells have primarily focussed on elemental analyses and their potential utility for isotope ratio analysis by MC-ICP-MS has not yet been fully investigated ${ }^{34}$.

\section{Experimental}

An ESI $^{\circledR}$ (New Wave Research ${ }^{\mathrm{TM}}$ ) UP193FX $193 \mathrm{~nm}$ excimer laser system was coupled to a Thermo Scientific ${ }^{\mathrm{TM}}$ Neptune Plus ${ }^{\mathrm{TM}}$ MC-ICP-MS. The MC-ICP-MS was equipped with a multiple ion counting (MIC) array to simultaneously measure ${ }^{234} \mathrm{U},{ }^{235} \mathrm{U}$ and ${ }^{236} \mathrm{U} .{ }^{238} \mathrm{U}$ was collected on a Faraday cup (Table 1 ) coupled to a $10^{11} \Omega$ amplifier.

Table 1 - Cup configuration on the Thermo Scientific ${ }^{\mathrm{TM}}$ Neptune Plus ${ }^{\mathrm{TM}}$ MC-ICP-MS. ${ }^{234} \mathrm{U}$ was collected on a compact discrete dynode rather than a full size SEM.

\begin{tabular}{ccccccc}
\hline Cup & IC 5 & IC 3 & IC 2 & IC 1 & L4 & C \\
\hline Detector & CDD & SEM & SEM & SEM & FAR $\left(10^{11} \Omega\right)$ & FAR $\left(10^{11} \Omega\right)$ \\
Mass & ${ }^{234} \mathrm{U}$ & ${ }^{235} \mathrm{U}$ & ${ }^{236} \mathrm{U}$ & 237.05 & ${ }^{238} \mathrm{U}$ & 255.5 \\
\hline
\end{tabular}

Two different laser ablation configurations were used to transport the laser plume from the ablation site to the plasma. The first, more established configuration used a low-volume single-volume cell, the zircon cell, developed by Horstwood et $a l^{43}$, which followed the work of Bleiner and Günther ${ }^{44}$ by restricting the internal volume to a flat-sided teardrop shape of c.a. $3 \mathrm{~cm}^{3}$. The helium ablation gas exited the cell along 1/8" ID Teflonlined Tygon tubing. Ar make-up gas and $\mathrm{N}_{2}$ sourced from the outlet of an Aridus ${ }^{\mathrm{TM}}$ desolvating nebuliser system (CETAC Technologies, Omaha, Nebraska) was mixed with the ablation gas via a Y-piece halfway between the cell and the injector. The total length of tubing used was $1.5 \mathrm{~m}$ and as a result the total internal volume of the configuration was c.a. $15 \mathrm{~cm}^{3}$.

The second configuration, incorporating a high speed, integrated ablation cell and dual concentric injector (DCI) developed at Loughborough University ${ }^{45}$ (Figure 1) was first described in Douglas et $a^{\beta 8}$. It consisted of three main components, an inner cell, an outer cell and the DCI. The inner cell, the micro "Sniffer" cell, sat about 100 
$\mu \mathrm{m}$ above the sample surface within the larger holding "Enterprise" outer cell. The inner cell had to remain stationary relative to the laser head and therefore the sample moves within the outer cell, and under the floating inner cell, by magnetic coupling. From the inner cell, a $250 \mu \mathrm{m}$ i.d. thin fused silica tube transported the ablated material to the injector. In the $\mathrm{DCl}$ the fused silica line was passed down the centre of a $2.0 \mathrm{~mm}$ quartz injector, hence acting as a secondary internal injector. Around the fused silica line was added the Ar make-up gas and $\mathrm{N}_{2}$, again sourced from an Aridus desolvating nebuliser system, creating a "sheath" around the He ablation gas.

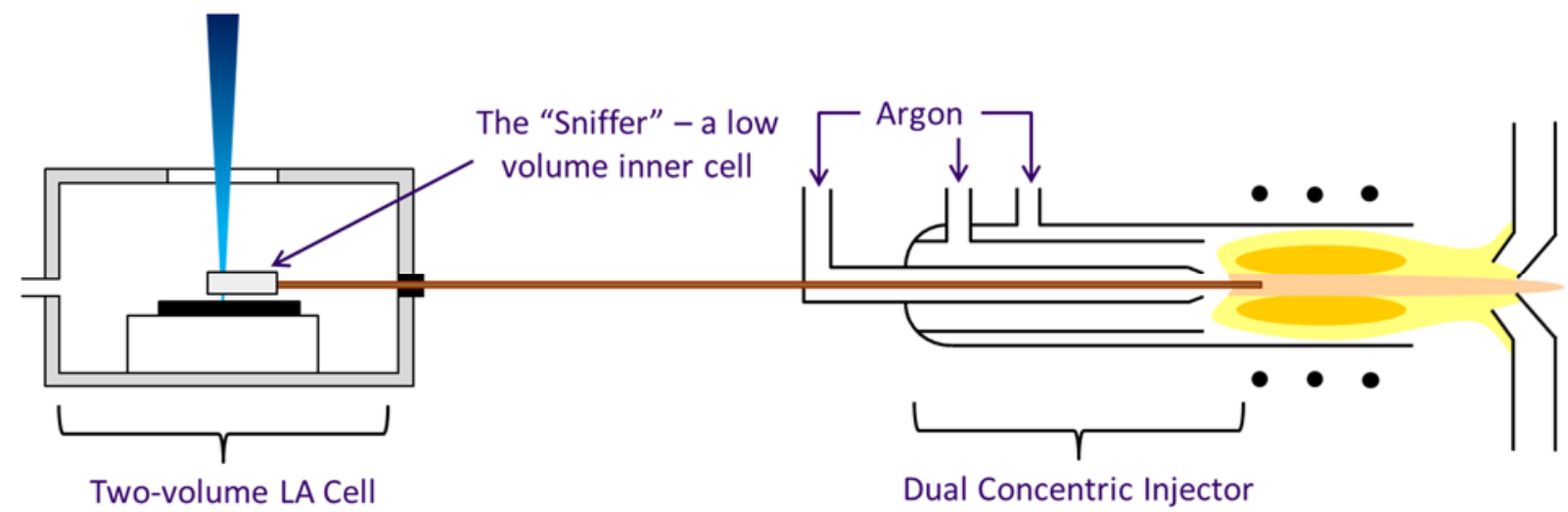

Figure 1 - The three components of the high speed, integrated ablation cell and DCl. Reproduction from Douglas et $a l^{\beta 8}$ The $\mathrm{DCl}$ system was intended to work in a close-coupled configuration in which the fused silica tubing was kept straight and did not exceed $30 \mathrm{~cm}$ in length, restricting the total volume to $0.015 \mathrm{~cm}^{3}$. Due to the size of the MCICP-MS such a close coupling was impossible and as a result in our configuration the fused silica tubing was both curved and increased in length to $150 \mathrm{~cm}$, resulting in a total volume of $0.075 \mathrm{~cm}^{3}$.

Table 2 - Operating parameters for LA-MC-ICP-MS, both laser ablation configurations.

\begin{tabular}{|c|c|c|}
\hline & Zircon Cell & $\mathrm{DCl}$ \\
\hline \multicolumn{3}{|c|}{ ESI ${ }^{\circledR}$ New Wave Research ${ }^{\top M}$ UP-193FX excimer laser } \\
\hline Ablation mode & Single spot & Single spot \\
\hline Fluence & $11 \mathrm{~J} \mathrm{~cm}^{-2}$ & $11 \mathrm{~J} \mathrm{~cm}^{-2}$ \\
\hline Repetition rate & $1 \mathrm{~Hz}$ & $1 \mathrm{~Hz}$ \\
\hline Spot size & $\begin{array}{l}5 \mu \mathrm{m}\left(\mathrm{UO}_{\mathrm{x}}\right) \\
20 \mu \mathrm{m}(\mathrm{SRM} 610)\end{array}$ & $\begin{array}{l}5 \mu \mathrm{m}\left(\mathrm{UO}_{\mathrm{x}}\right) \\
20 \mu \mathrm{m}(\mathrm{SRM} 10)\end{array}$ \\
\hline He carrier gas & $0.8 \mathrm{~L} \mathrm{~min}^{-1}$ & $9 \mathrm{~mL} \min ^{-1}$ \\
\hline Cell Pressure & $\approx 0 \mathrm{k} \cdot \mathrm{Pa}$ & 77 k.Pa \\
\hline \multicolumn{3}{|l|}{ CETAC Aridus $^{T M}$ I } \\
\hline Nebulizer & PFA 50 & PFA 50 \\
\hline Sweep gas & $3.5 \mathrm{~L} \mathrm{~min}^{-1}$ & $5.3 \mathrm{~L} \mathrm{~min}^{-1}$ \\
\hline N2 add gas & $9 \mathrm{~mL} \mathrm{~min}-1$ & $9 \mathrm{~mL} \min ^{-1}$ \\
\hline \multicolumn{3}{|c|}{ Thermo Scientific ${ }^{T M}$ Neptune Plus ${ }^{T M} M C-I C P-M S$} \\
\hline RF power & $1170 \mathrm{~W}$ & $1170 \mathrm{~W}$ \\
\hline
\end{tabular}




\begin{tabular}{|l|l|l|}
\hline Cool gas & $15 \mathrm{~L} \mathrm{~min}^{-1}$ & $15 \mathrm{~L} \mathrm{~min}^{-1}$ \\
\hline Aux. gas & $0.9 \mathrm{~L} \mathrm{~min}^{-1}$ & $0.9 \mathrm{~L} \mathrm{~min}$ \\
\hline Skimmer cone & $\mathrm{X}$ & $\mathrm{X}$ \\
\hline Sampler cone & Jet & Jet \\
\hline Sample Gas & $0.82 \mathrm{~L} \mathrm{~min}^{-1}$ & $0.82 \mathrm{~L} \mathrm{~min}^{-1}$ \\
\hline
\end{tabular}

Correction factors were determined from solutions of known uranium isotopic composition introduced via the Aridus desolvating nebulizer prior to LA analysis. Certified reference material (CRM) 112A (New Brunswick Laboratory, US Department of Energy, Washington DC, USA) ${ }^{46}$ with concentration $<15$ ppb in no more than $2 \%$ $(\mathrm{m} / \mathrm{m}) \mathrm{HNO}_{3}$, was used to calculate the $\mathrm{UH}^{+} / \mathrm{U}^{+}$and abundance sensitivity. CRM U010 (New Brunswick Laboratory, US Department of Energy, Washington DC, USA $)^{47}$ was used to determine correction factors for mass bias and relative detector gain.

Laser ablation of a single solid reference material, NIST SRM ${ }^{\circledR} 611$ (National Institute of Standards and Technology, Gaithersburg, Maryland, USA, $461.5 \pm 1.1 \mathrm{ppm} \mathrm{U})^{48}$ was used to compare the different instrumental configurations.

The Institute for Reference Materials and Measurements (IRMM) have so far carried out eight Nuclear Signatures Inter-laboratory Measurement Evaluation Programme (NUSIMEP) inter-laboratory comparisons (ILC). Two of these, NUSIMEP-6 and NUSIMEP-7, took the form of sub-micron uranium oxide particles of known composition coated onto carbon planchets ${ }^{25,27}$ and as such are useful reference materials to evaluate the ability of LA-ICP-MS to analyse such samples. The particles analysed in this study, composed of $\mathrm{U}_{3} \mathrm{O}_{8}$, were from both NUSIMEP-6 and NUSIMEP-7. NUSIMEP-6 consisted of a single graphite planchet with particles of a single isotopic composition condensed onto it. NUSIMEP-7 used two planchets, one containing particles of a single isotopic composition and another containing particles of two different compositions, the 'double composition' planchet. Reference uranium isotope ratios for the particles on each planchet are given in Table 3.

Table 3 - Reference uranium Isotope ratios of NIST SRM 611 and NUSIMEP particles

\begin{tabular}{|c|c|c|c|c|}
\hline & & ${ }^{234} U /{ }^{238} U$ & ${ }^{235} U /{ }^{238} U$ & ${ }^{236} U /{ }^{238} U$ \\
\hline SRM611 $^{49}$ & & $1.0024 \mathrm{e}-05$ & $2.3818 \mathrm{e}-03$ & $4.3104 \mathrm{e}-05$ \\
\hline NUSIMEP-6 ${ }^{25}$ & & 4.9817e-05 & 7.0439e-03 & $5.2048 \mathrm{e}-07$ \\
\hline NUSIMEP-7 (1) & & $7.4365 e-05$ & $9.0726 \mathrm{e}-03$ & $8.0205 e-06$ \\
\hline \multirow[t]{2}{*}{ NUSIMEP-7 (2) ${ }^{26}$} & $1^{\text {st }}$ & $7.4365 e-05$ & $9.0726 \mathrm{e}-03$ & $8.0205 e-06$ \\
\hline & $2^{\text {nd }}$ & $3.4514 \mathrm{e}-04$ & $3.4148 \mathrm{e}-02$ & $1.03268 \mathrm{e}-04$ \\
\hline
\end{tabular}

Due to the dynamic range required to detect and appropriately measure all uranium isotopes, a mixed detector array of Faraday cups and ion counters was required. Across the acquisition period of a transient signal (generated by either laser ablation or gas chromatography) using MC-ICP-MS, systematic isotope ratio drift has 
been observed $36,37,50,51$. The cause of the isotope ratio drift in such cases has been identified as different tau response rates on the associated Faraday detector amplifiers ${ }^{50}$, and approaches to correct for the different amplifier tau response rates have been developed ${ }^{31,51-54}$. For our analysis the difference in response rate was expected to be more pronounced; without a high resistance amplification circuit, the ion counter response is near instantaneous. We adopted the approach of Cottle et $a^{\beta 0}{ }^{3}$, who measured a response delay of ca. 0.2 seconds between ion counter and Faraday cup signals during single shot LA-MC-ICP-MS. This response delay strongly affected the accuracy of the isotope ratio when calculated on a time-slice (cycle-by-cycle) basis. As a consequence the integrated area for each individual isotope was used to calculate the ratios for each pulse; that is total signal integration (TSI).

\section{Results}

\section{Uranium Isotope Ratio Measurement of SRM 611}

Uranium isotope ratios of SRM 611 were calculated for each of 300 single shot ablations. For the ion counters total peak width averaged 506 milliseconds for the Zircon Cell and 109 milliseconds for the Enterprise Cell and DCl (Figure 2).
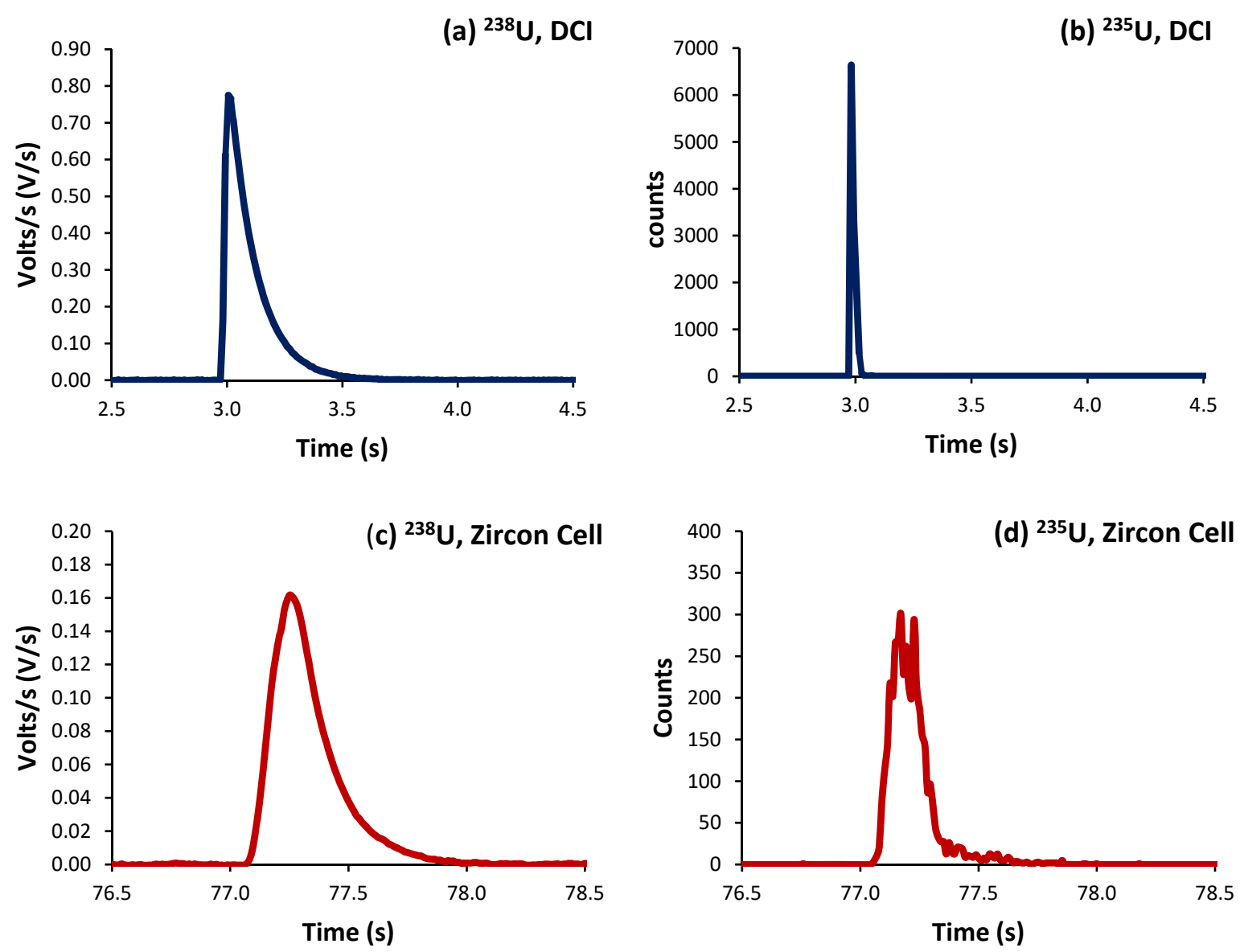

Figure 2 - Four single-shot laser ablation profiles of uranium isotopes in SRM 611, integration time 8 ms. (a) and (b) are ablations from the high speed, integrated cell and DCI; (c) and (d) the Zircon Cell. (a) and (c) were collected on a Faraday detector; (b) and (d) on an ion counter. 
The reduction in peak width using the $\mathrm{DCl}$ increased the signal-to-noise ratio by a factor of 25 and improved the definition of the minor ( ${ }^{234} \mathrm{U}$ and ${ }^{236} \mathrm{U}$ ) isotopes. However, due to the slow Faraday amplifier response an average peak width significantly greater than 109 milliseconds was measured for ${ }^{238} \mathrm{U}$ (Fig 4). To calculate an isotope ratio from such divergent peak profiles proved the necessity of the TSI data evaluation strategy. The three uranium isotope ratios, ${ }^{234} \mathrm{U} /{ }^{238} \mathrm{U},{ }^{235} \mathrm{U} /{ }^{238} \mathrm{U}$ and ${ }^{236} \mathrm{U} /{ }^{238} \mathrm{U}$, were determined for the 300 ablation shots collected with both laser ablation systems (Table 4).

Table 4 - Mean uranium isotope ratios of 300 single shots on SRM 611 for both laser ablation configurations. Integration time $=66 \mathrm{~ms}$.

\begin{tabular}{|c|c|c|c|c|c|c|}
\hline & \multicolumn{3}{|c|}{ Zircon Cell } & \multicolumn{3}{|c|}{$\mathrm{DCl}$ and Enterprise Cell } \\
\hline & ${ }^{234} U /{ }^{238} U$ & ${ }^{235} U /{ }^{238} \mathrm{U}$ & ${ }^{236} \mathrm{U} /{ }^{238} \mathrm{U}$ & ${ }^{234} U /{ }^{238} U$ & ${ }^{235} U /{ }^{238} U$ & ${ }^{236} U /{ }^{238} U$ \\
\hline Mean & $1.04 \mathrm{E}-05$ & $2.35 \mathrm{E}-03$ & 4.55E-05 & $1.05 \mathrm{E}-05$ & $2.34 \mathrm{E}-03$ & 4.56E-05 \\
\hline -SD (\%) † & 15.7 & 1.33 & 7.38 & 13.2 & 2.89 & 7.62 \\
\hline +SD (\%) † & 18.6 & 1.35 & 7.96 & 15.2 & 2.97 & 8.24 \\
\hline Relative Difference (\%) * & 9.64 & -1.50 & 5.29 & 10.4 & -1.93 & 5.53 \\
\hline Counting Statistics SE (\%) & 16.8 & 1.11 & 8.18 & 15.1 & 0.99 & 7.28 \\
\hline
\end{tabular}

† Geometric mean: non-symmetric log-normal distribution, confidence intervals either side of the mean are not identical.

* Relative Difference $=($ Geometric Mean/Reference Value $)-1$

For the Zircon Cell the three uranium isotope ratios were accurate, within uncertainty, to the reference values and the precision closely tracked the values predicted from counting statistics. The increased detection efficiency and signal-to-noise ratio of the $\mathrm{DCl}$ and Enterprise cell did not however, translate into a comparative improvement in precision. The ${ }^{235} \mathrm{U} /{ }^{238} \mathrm{U}$ SD of 2.9-3.0\% was three times larger than counting statistics (0.99 \%). Plots of ${ }^{235} \mathrm{U} /{ }^{238} \mathrm{U}$ for each pulse (Figure 3) confirmed the wider distribution of ratios with the DCl, with outliers biased towards a more depleted ${ }^{235} \mathrm{U}$ composition. Given the broadly similar count rates with both laser ablation systems, results suggested the introduction of the $\mathrm{DCl}$ had introduced a new source of imprecision. A possible source of the additional uncertainty ('blind time') was investigated.
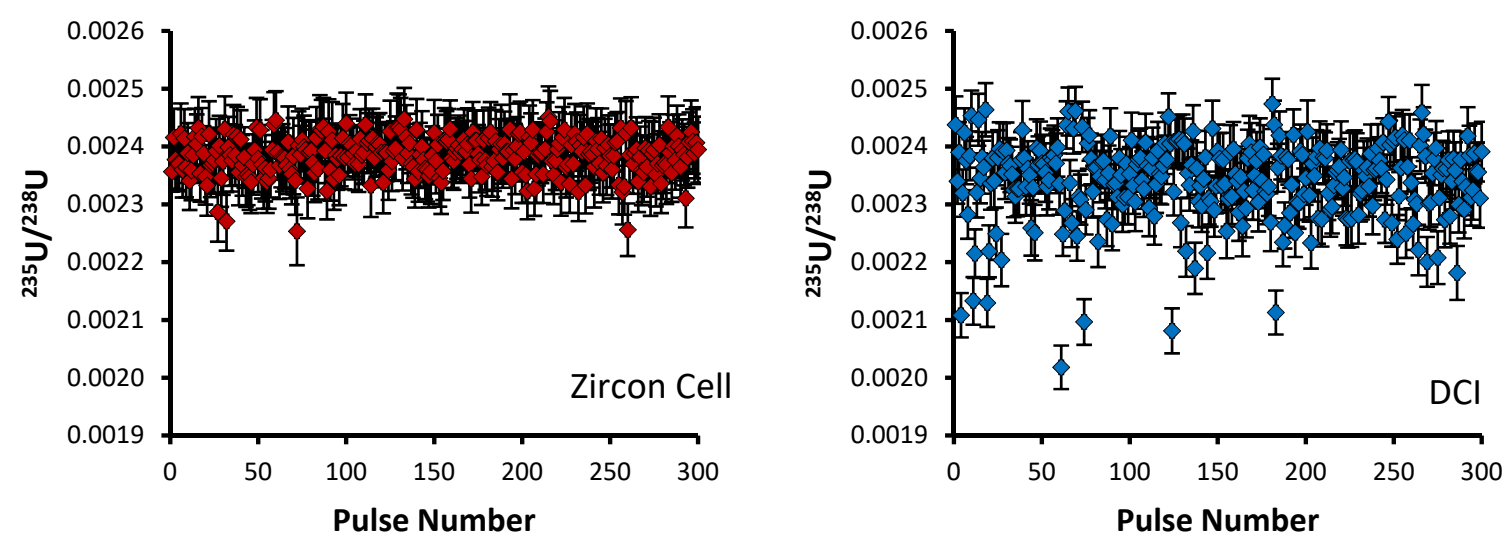
Figure $3-{ }^{235} \mathrm{U} /{ }^{238} \mathrm{U}$ isotope ratios of 300 pulses on SRM611 glass, calculated by total signal integration. Plot on the left (red) is for the Zircon Cell, plot on the right (blue) the DCI. Error bars on each ratio are 2SE, determined from counting statistics. All of the pulses collected with the Zircon Cell describe a single population within 2SD. Some pulses collected with the $\mathrm{DCl}$ had depleted ${ }^{235} \mathrm{U} /{ }^{238} \mathrm{U}$ values, out with uncertainty, relative to the main population.

\section{'Blind Time' - Undetected lons between Integrations}

In the Neptune MC-ICP-MS software there is a discrepancy between how different integration times are identified, e.g. '66 ms', and the integration time of the data output, e.g. '68-69 ms'. For the example $66 \mathrm{~ms}$ integration time, the output of each integration is divided into three sections; a main 59ms section; a secondary $7 \mathrm{~ms}$ section and the final 2 or $3 \mathrm{~ms}$ (average $2.37 \mathrm{~ms}$ over 10,000 integrations) residual time. The three sections are a legacy of the data acquisition system for the Faraday cups, which was developed with the collection of continuous signals in mind ${ }^{37}$. During operation the Faraday cups generate an analogue current. The analogue current is subsequently digitized using voltage to frequency conversion (by an analogue-to-digital converter). In this application rather than encoding the size of the signal, the change in the signal is encoded instead (removing any quantisation error). The current from the Faraday is therefore converted into a stream of digital pulses. For volt level signals on the Faraday the pulses occur at a frequency in the kHz range. If measured within a fixed time window in the $\mathrm{kHz}$ (millisecond) range the next pulse could occur either inside or outside of the window, limiting the precision to an integer unit per mille. To achieve precision levels in the parts per million (ppm) range, requires the timing to a subsequent pulse to be measured against a fast, $\mathrm{MHz}$, clock. It is this fast clock measurement which occurs in the secondary section $(7 \mathrm{~ms})$ of the integration. At the end of the integration the system resets to the slower, $\mathrm{kHz}$, clock. Once reset, the detector system waits until the next digital pulse is detected before beginning the next integration. It is the delay in waiting for the next pulse on each channel which is responsible for the extra time, known here as "blind time" ${ }^{\prime 55}$. During blind time the mass spectrometer is effectively dead; no signal is recorded, on either the Faraday cups or ion counters. With the $66 \mathrm{~ms}$ integration time, only $96.4 \%$ of a continuous signal is being detected (Table 5). Interestingly, this indicates that due to the tau decay constant being longer than the integration time and therefore encompassing multiple blind time events, $100 \%$ of the signal is never detected using Faraday detection and maximum precision is degraded using shorter integrations times where proportionately more of the signal is lost during the 'blind time'.

Table 5 - Calculation of percentage of time lost due to blind time per integration. All values are an average of 2000 cycles.

\begin{tabular}{llll}
\hline Integration Time & Total Time & Blind Time & \% Lost \\
\hline $\mathbf{8 ~} \mathbf{~ s s}$ & $11.50 \mathrm{~ms}$ & $3.50 \mathrm{~ms}$ & $30.4 \%$ \\
$\mathbf{6 6} \mathbf{~ m s}$ & $68.47 \mathrm{~ms}$ & $2.47 \mathrm{~ms}$ & $3.61 \%$ \\
$\mathbf{1 3 1} \mathrm{ms}$ & $134.3 \mathrm{~ms}$ & $3.28 \mathrm{~ms}$ & $2.44 \%$ \\
$\mathbf{2 6 2} \mathrm{ms}$ & $265.3 \mathrm{~ms}$ & $3.31 \mathrm{~ms}$ & $1.25 \%$ \\
$\mathbf{5 2 4} \mathbf{~ m s}$ & $527.8 \mathrm{~ms}$ & $3.82 \mathrm{~ms}$ & $0.72 \%$ \\
$\mathbf{1 0 4 9} \mathbf{m s}$ & $1051.4 \mathrm{~ms}$ & $2.44 \mathrm{~ms}$ & $0.23 \%$ \\
\hline
\end{tabular}


The $8 \mathrm{~ms}$ integration time apart, it can be assumed that such short interruptions in data collection will have a negligible effect on either continuous or semi-continuous signal responses. However, for transient signals collected on a mixed detector array, 'blind time' may have a significant impact on isotope ratio analysis.

In order to test the effect of blind time on isotope ratio measurement with the $\mathrm{DCl}$, a model was created. 30 single shot laser ablation pulses on SRM 611, collected with both laser ablation configurations, were merged to produce an 'average' single shot ablation profile for each type of detector. To these average response profiles Exponential Modified Gaussian functions were fitted using the software package Igor Pro ${ }^{\mathrm{TM}}$ (version 6.36, Wavemetrics, Oregon, USA) and the Multipeak Fitting function ${ }^{38}$. The parameters generated were used in conjunction with the Exponential-Gaussian Hybrid function ${ }^{56}$ to produce four model laser ablation pulses, one for each combination of laser ablation configuration and detector type (Figure 4). The integration time used in the model curves was $3 \mathrm{~ms}$, a value close to the average measured blind time. By removing integrations every $66 \mathrm{~ms}, 131 \mathrm{~ms}$ etc, and at each possible start time, the range of signal which could potentially be lost on each detector was calculated.

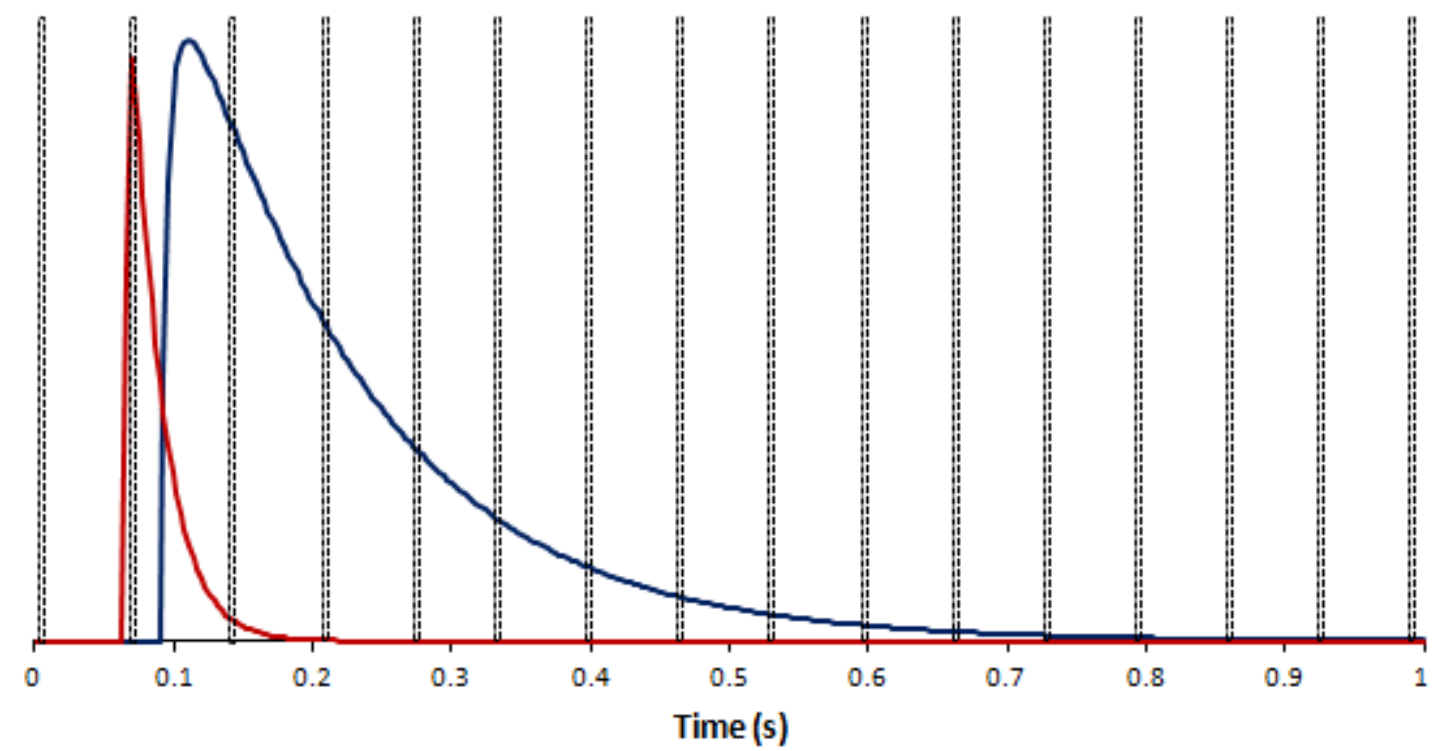

Figure 4 - Model ${ }^{235} \mathrm{U}$ IC signal response (red) and ${ }^{238} \mathrm{U}$ Faraday detector signal response (blue) for the DCl: created with the determined Exponential Gaussian Hybrid functions, values every $3 \mathrm{~ms}$. Blind time events (black dotted box) denote an example $66 \mathrm{~ms}$ integration time. The proportion of total counts lost to blind time differs between the IC and Faraday signal responses.

In the plot of a model DCI pulse (Figure 4), the signal collected on the IC is interrupted by two blind time events, in contrast to the 9 blind time events which interrupt the output of the Faraday signal. If the proportion of signal lost is different between the two detectors this would introduce a bias to the determined isotope ratio.

Table 6 - Estimated percentage range of total signal which could be lost due to blind time on each detector, integration time $=66 \mathrm{~ms}$. 


\begin{tabular}{c|ccc|ccc|c}
\hline & \multicolumn{3}{|c|}{ Faraday ${ }^{238} \mathrm{U}$} & \multicolumn{3}{c|}{ SEM - ${ }^{235} \mathrm{U}$} & ${ }^{235} \mathrm{U} /{ }^{\mathbf{2 3 8} U}$ \\
& Min Signal & Max Signal & Range & Min Signal & Max Signal & Range & Estimated \\
& Lost (\%) & Lost (\%) & (\%) & Lost (\%) & Lost (\%) & (\%) & RSD (\%) \\
\hline Zircon Cell & 4.21 & 4.44 & 0.23 & 4.13 & 4.55 & 0.42 & 0.15 \\
DCI & 3.50 & 5.00 & 1.50 & 0.67 & 11.20 & 10.53 & 2.76 \\
\hline
\end{tabular}

The ultrafast single shot profiles of the $\mathrm{DCl}$ more strongly affected the percentage of total signal which could be lost to blind time on the ion counters compared to the Faraday detector. Using the model it was estimated, with $66 \mathrm{~ms}$ integration (Table 6), blind time could be responsible for at most $0.15 \%$ RSD ${ }^{235} \mathrm{U} /{ }^{238} \mathrm{U}$ on the mean single shot ablation pulses collected with the Zircon Cell, but up to $2.76 \%$ RSD with the DCI. The model supported the hypothesis that blind time was responsible for the additional ${ }^{235} \mathrm{U} /{ }^{238} \mathrm{U}$ uncertainty with the $\mathrm{DCl}$. To further bolster the blind time hypothesis more single shot ablation pulses were collected on NIST 611, this time using a $262 \mathrm{~ms}$ integration time instead of $66 \mathrm{~ms}$. As the average peak width on the SEM was only $109 \mathrm{~ms}$, the ${ }^{235} \mathrm{U}$ signal collected could either be contained within a single integration, or split between two integrations with blind time in between. The model suggested for a $262 \mathrm{~ms}$ integration time ${ }^{238} \mathrm{U}$, collected on a Faraday detector, would lose between $0.34-2.16 \%$ of signal due to blind time events. ${ }^{235} \mathrm{U}$ would either lose no counts, resulting in a slightly enriched ${ }^{235} \mathrm{U} /{ }^{238} \mathrm{U}$ ratio, or lose up to $10.7 \%$ and give a depleted ${ }^{235} \mathrm{U} /{ }^{238} \mathrm{U}$ ratio. For our experimental particle data the ${ }^{235} \mathrm{U} /{ }^{238} \mathrm{U}$ ratio was plotted against the percentage of the total ${ }^{235} \mathrm{U}$ signal captured in the first integration (Figure 5), as if the model holds particle data with approximately $50 \%$ of the total signal in the first integration would be most likely to exhibit blind time effects.

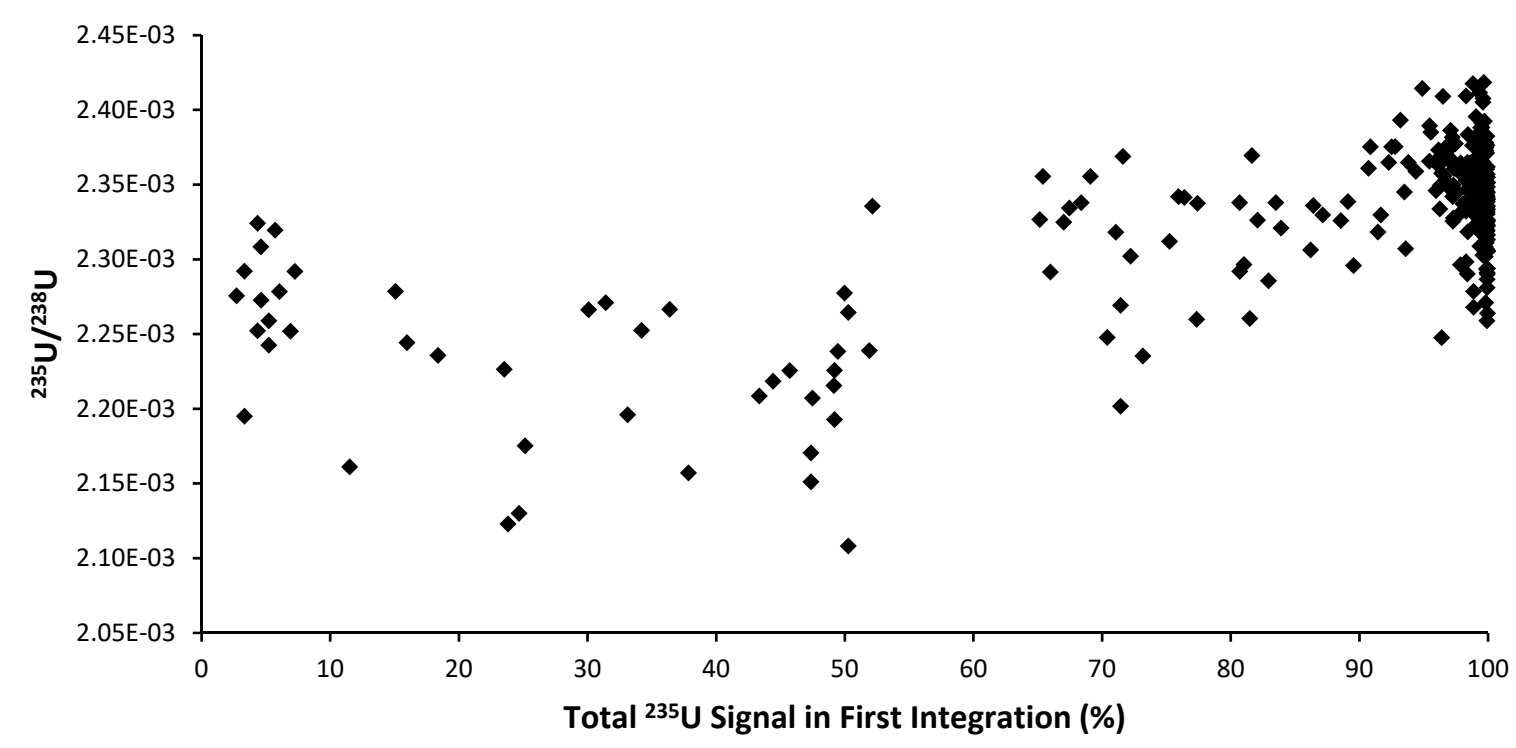

Figure 5 - Plot of ${ }^{235} \mathrm{U} /{ }^{238} \mathrm{U}$ for single-shot laser ablation pulses on SRM 611, integration time $262 \mathrm{~ms}$, against the percentage of ${ }^{235} \mathrm{U}$ signal contained within the first integration. Pulses with $100 \%$ of the ${ }^{235} \mathrm{U}$ signal in a single integration were biased higher relative to pulses split between two integrations. 
In the plot the majority of pulses with $100 \%$ of the ${ }^{235} \mathrm{U}$ signal in a single integration had a higher ${ }^{235} \mathrm{U} /{ }^{238} \mathrm{U}$ ratio, than those pulses where the ${ }^{235} \mathrm{U}$ signal was interrupted by blind time, consistent with the theoretical model.

\section{Strategies to Reduce 'Blind Time’ for Ultrafast Transient Signal Analysis}

Increasing the integration time from $66 \mathrm{~ms}$ to $262 \mathrm{~ms}$ reduced the proportion of pulses with significantly depleted ${ }^{235} \mathrm{U} /{ }^{238} \mathrm{U}$ ratios. By reducing the number of blind time events the likelihood of blind time occurring at the maxima of ${ }^{235} \mathrm{U}$ counts was also reduced. However increasing the integration time did not eliminate blind time completely and furthermore opened up the possibility of enriched ${ }^{235} \mathrm{U} /{ }^{238} \mathrm{U}$ ratios by capturing the entire SEM output within a single integration. For particle analysis, where a single particle could represent the entire population of one composition, any bias due to blind time could seriously bias data interpretation.

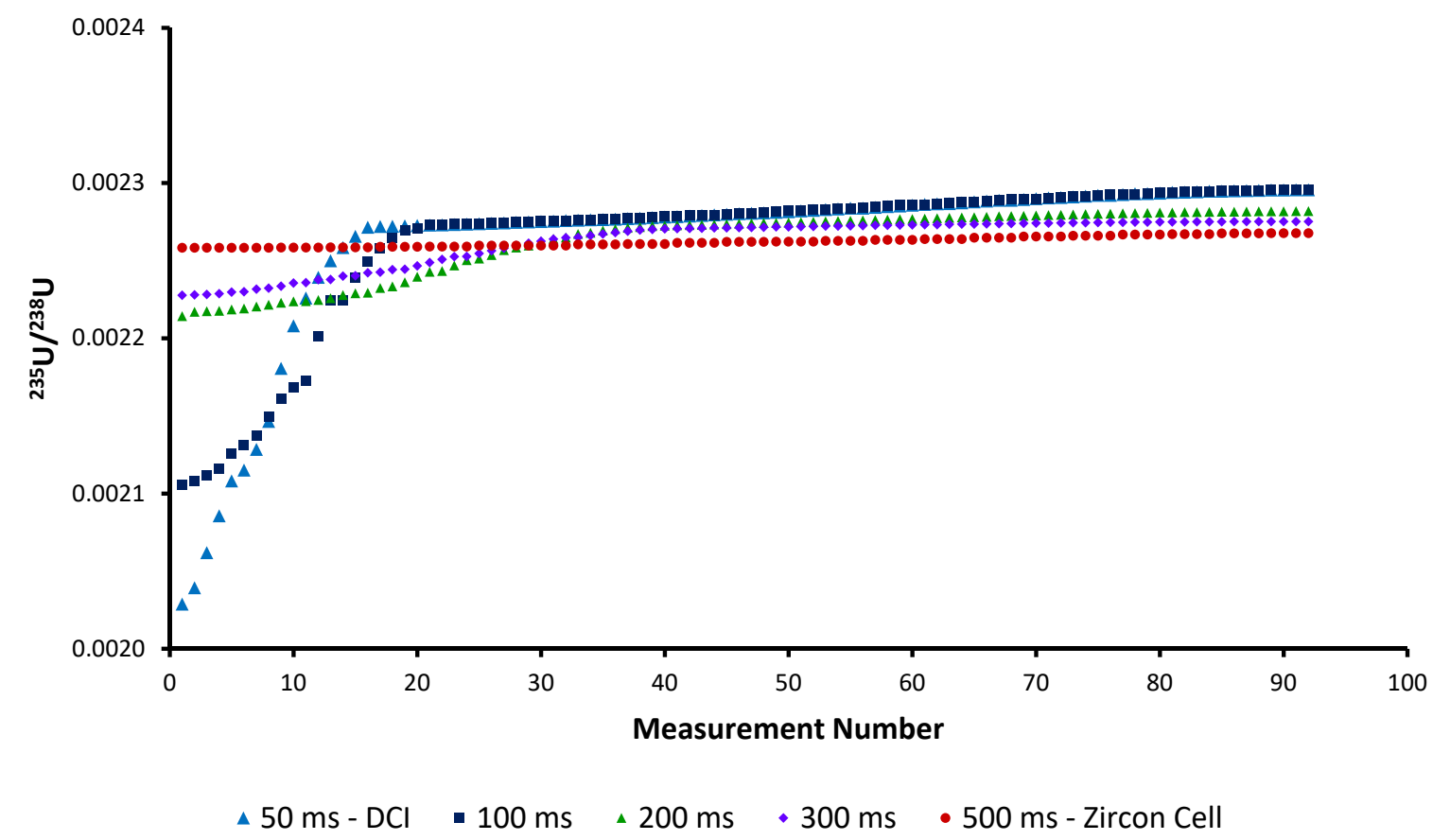

Figure 6 - Plot of possible ${ }^{235} \mathrm{U} /{ }^{238} \mathrm{U}$ isotope ratios for the average model pulse due to the influence of blind time. The $100-300$ ms datasets were created by widening the model IC pulse via changes to the parameters in the ExponentialGaussian Hybrid function. As the pulse duration increased the impact of blind time on isotope ratio accuracy was reduced.

The existence of blind time in some models of MC-ICP-MS may prevent the successful analysis of ultrafast transient signals. Until such time as next-generation instrumentation is developed, it is important to understand the minimum transient signal duration required in order for every ratio to be unaffected by blind time in LA-MCICP-MS set-ups. To estimate this value the parameters of the blind time model were modified to create results for pulses of approximately 50, 100, 200 and 300 ms duration. Each increase in pulse duration reduced the impact of blind time on the isotope ratio precision (Figure 6). From this figure we can conclude that reducing the transient signal duration much below the $0.5 \mathrm{~s}$ achieved by the Zircon Cell will lead to blind time effects on 
ultrafast transient isotope ratio analyses. As such the reported washout times of most commercially available two-volume laser ablation cells $(\leq 1 \mathrm{~s})^{57}$ may represent the best compromise for particle analysis with current MC-ICP-MS systems.

\section{Effect of Blind Time on Isotope Ratio Measurement of Sub-Micron Uranium Particles}

\section{NUSIMEP-6}

A large number (Zircon Cell $=300$ shots, $\mathrm{DCl}=500$ shots) of single-shot laser ablation pulses, spot size $5 \mu \mathrm{m}$, were conducted on the NUSIMEP-6 planchet. The $5 \mu \mathrm{m}$ spot size was much less than the average spacing between particles determined by SEM-EDX, reducing the risk of simultaneously ablating more than one particle. However, the NUSIMEP-6 planchet has been described elsewhere as possessing a "smear" of uranium material across its surface ${ }^{27}$, alongside discrete particles. As a result almost every laser shot resulted in some uranium signal. The mean ${ }^{238} \mathrm{U}$ counts for each single-shot ablation of the NUSIMEP-6 planchet was double that for SRM 611. From the density of $\mathrm{U}_{2} \mathrm{O}_{3}$ and the concentration of uranium in SRM 611, it was calculated that the mean SRM 611 signal would be equivalent to a $\sim 150 \mathrm{~nm}$ diameter $\mathrm{U}_{2} \mathrm{O}_{3}$ particle. Due to the extremely low abundance of ${ }^{236} \mathrm{U}$ in the NUSIMEP-6 particles the average ${ }^{236} \mathrm{U}$ counts detected was less than 15 counts. Consequently the ${ }^{236} \mathrm{U} /{ }^{238} \mathrm{U}$ isotope ratio values are not reported.

From the ${ }^{235} \mathrm{U} /{ }^{238} \mathrm{U}$ ratios obtained it was observed that particles, regardless of laser ablation configuration, seemed to be affected by blind time effects. This had been expected for the ultrafast DCl, but not the Zircon Cell. Those particles affected with the Zircon Cell were those single-shot ablation peak profiles which were interrupted with spikes in signal, of single integration duration (Figure 7). The occurrence of such spikes was very strongly correlated with bias towards depleted uranium isotope ratios. Each spike was thought to represent the entrainment of a whole particle, or large fragment, into the plasma. Unlike the rest of the signal profile, these highly transient spikes would be susceptible to blind time effects. 


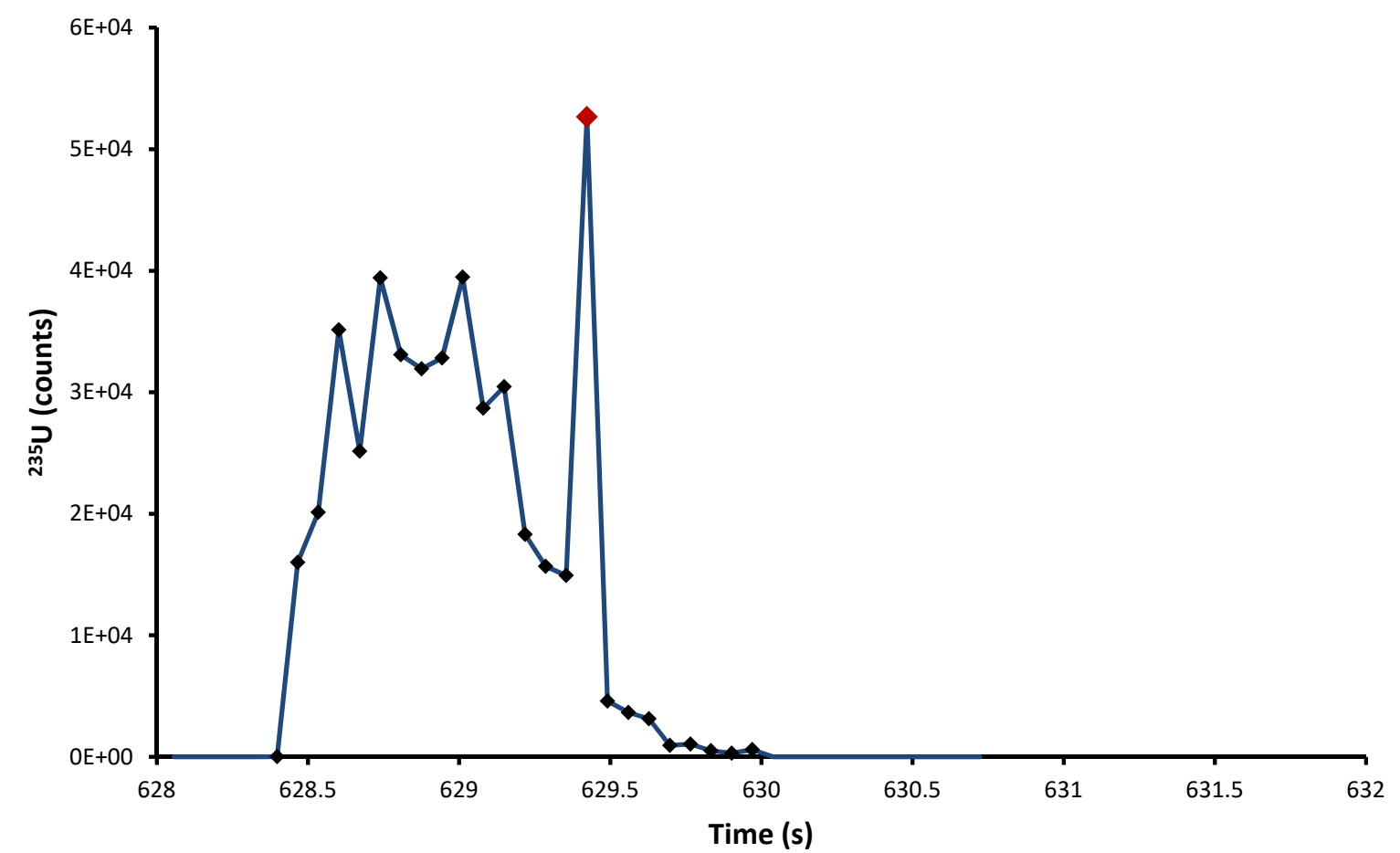

Figure $7-{ }^{235} \mathrm{U}$ pulse profile of the ablation of a NUSIMEP-6 particle, Zircon Cell. The standard profile is interrupted by a large single integration spike in the signal.

To filter out the biased signals the application Flexmix, a software package in $\mathrm{R}$, described by Kappel et $\left.a\right|^{22}$ was used to assign strongly biased signals to a separate cluster. The particles isolated in the separate cluster were not used to determine the average uranium isotope ratios (Table 7).

Table 7 - Mean isotope ratio results for NUSIMEP-6. Zircon Cell, $n=253$. DCl and Enterprise Cell, $n=480$. Integration time = $66 \mathrm{~ms}$.

\begin{tabular}{lllll}
\hline & \multicolumn{2}{c}{ Zircon Cell } & \multicolumn{2}{c}{ DCI } \\
& ${ }^{234} \mathrm{U} /{ }^{238} \mathrm{U}$ & ${ }^{235} \mathrm{U} /{ }^{\mathbf{2 3 8}} \mathrm{U}$ & ${ }^{234} \mathrm{U} /{ }^{238} \mathrm{U}$ & ${ }^{235} \mathrm{U} /{ }^{\mathbf{2 3 8}} \mathrm{U}$ \\
\hline Mean & $4.92 \mathrm{E}-05$ & $6.76 \mathrm{E}-03$ & $4.76 \mathrm{E}-05$ & $6.80 \mathrm{E}-03$ \\
-SD (\%) & 7.66 & 2.93 & 9.54 & 2.79 \\
+SD (\%) & 8.29 & 3.01 & 10.6 & 2.87 \\
RD (\%) & -1.21 & -4.05 & -4.49 & -2.84 \\
-SE (\%) & 0.45 & 0.17 & 0.44 & 0.13 \\
+SE (\%) & 0.48 & 0.18 & 0.48 & 0.13 \\
\hline
\end{tabular}

\section{NUSIMEP-7 (single composition)}

As expected the single composition NUSIMEP-7 planchet did not return a uranium signal with every ablation pulse. Out of 1000 shots at 9 different locations across the planchet only 277 (27.7\%) detected uranium material. Another 500 shots focussed on the centre of the planchet had a higher success rate of $82 \%$. The Flexmix package 
was used to separate outliers such as those shown in Figure 7. The theoretical RSE determined from counting statistics were $21.8 \%$ and $61.4 \%$ for ${ }^{234} \mathrm{U} /{ }^{238} \mathrm{U}$ and ${ }^{236} \mathrm{U} /{ }^{238} \mathrm{U}$ respectively. The high uncertainties (Table 8) reported for the minor isotope ratios, ${ }^{234} \mathrm{U} /{ }^{238} \mathrm{U}$ and ${ }^{236} \mathrm{U} /{ }^{238} \mathrm{U}$, were a consequence of the low number of detected ions. The precision on the ${ }^{235} \mathrm{U} /{ }^{238} \mathrm{U}$ ratio was not count rate limited $(2.2 \% 1 \mathrm{SD})$ : the additional uncertainty determined for both ablation cells was attributable to blind time.

Table 8 - Mean isotope ratio results for NUSIMEP-7 (single composition). Zircon Cell, n=349. DCl and Enterprise Cell, $n=202$. Integration time $=66 \mathrm{~ms}$.

\begin{tabular}{|c|c|c|c|c|c|c|}
\hline & \multicolumn{3}{|c|}{ Zircon Cell } & \multicolumn{3}{|c|}{$\mathrm{DCl}$ and Enterprise Cell } \\
\hline & ${ }^{234} U /{ }^{238} U$ & ${ }^{235} U /{ }^{238} U$ & ${ }^{236} U /{ }^{238} U$ & ${ }^{234} U /{ }^{238} U$ & ${ }^{235} U /{ }^{238} U$ & ${ }^{236} U /{ }^{238} U$ \\
\hline Mean & $7.97 \mathrm{E}-05$ & 8.97E-03 & $1.18 \mathrm{E}-05$ & $7.78 \mathrm{E}-05$ & $8.86 \mathrm{E}-03$ & 9.59E-06 \\
\hline -SD (\%) & 21.5 & 3.63 & 44.0 & 21.6 & 4.77 & 43.8 \\
\hline +SD (\%) & 27.4 & 3.76 & 78.6 & 27.6 & 5.01 & 78.0 \\
\hline Relative Difference (\%) & 6.91 & -1.19 & 38.3 & 4.47 & -2.36 & 17.8 \\
\hline -SE (\%) & 1.15 & 0.19 & 2.35 & 1.52 & 0.34 & 3.08 \\
\hline +SE (\%) & 1.47 & 0.20 & 4.20 & 1.94 & 0.35 & 5.49 \\
\hline
\end{tabular}

\section{NUSIMEP-7 (double composition)}

The dual composition NUSIMEP-7 planchet was analysed with the same conditions as the single composition planchet. Particles of both expected compositions were detected in roughly equal quantities. A significant proportion of the measured ablation pulses had uranium isotopic compositions of neither expected composition, but instead fitted onto a 'mixing line' between the two expected compositions. This was not unexpected, given how the planchet was assembled ${ }^{26}$. The Flexmix software package was again used to group the particles into clusters, with two of the clusters representing each expected composition (Table 9).

Table 9 - Mean isotope ratio results for NUSIMEP-7 (double composition). Integration time $=66 \mathrm{~ms}$.

\begin{tabular}{|c|c|c|c|c|c|c|c|c|}
\hline \multirow[b]{2}{*}{$1^{\text {st }}$ Composition } & \multirow[b]{2}{*}{$\mathbf{n}$} & \multirow[b]{2}{*}{${ }^{234} U /{ }^{238} U$} & \multicolumn{3}{|l|}{ Zircon Cell } & \multicolumn{3}{|c|}{$\mathrm{DCl}$ and Enterprise Cell } \\
\hline & & & ${ }^{235} U /{ }^{238} U$ & ${ }^{236} U /{ }^{238} U$ & $n$ & ${ }^{234} U /{ }^{238} U$ & ${ }^{235} U /{ }^{238} U$ & ${ }^{236} U /{ }^{238} U$ \\
\hline Mean & 73 & $7.43 \mathrm{E}-05$ & 8.72E-03 & $1.12 \mathrm{E}-05$ & 104 & $7.75 \mathrm{E}-05$ & 9.05E-03 & $1.40 \mathrm{E}-05$ \\
\hline -SD (\%) & & 8.49 & 3.27 & 30.0 & & 12.8 & 6.80 & 35.6 \\
\hline +SD (\%) & & 9.27 & 3.38 & 42.1 & & 14.7 & 7.30 & 55.3 \\
\hline $\begin{array}{l}\text { Relative } \\
\text { Difference (\%) }\end{array}$ & & -0.04 & -3.97 & 33.10 & & 4.14 & -0.23 & 55.83 \\
\hline -SE (\%) & & 0.99 & 0.38 & 3.51 & & 1.26 & 0.67 & 3.49 \\
\hline +SE (\%) & & 1.09 & 0.40 & 5.02 & & 1.44 & 0.72 & 5.43 \\
\hline $2^{\text {nd }}$ Composition & $\mathrm{n}$ & ${ }^{234} U /{ }^{238} U$ & ${ }^{235} U /{ }^{238} U$ & ${ }^{236} U /{ }^{238} U$ & $\mathrm{n}$ & ${ }^{234} U /{ }^{238} U$ & ${ }^{235} U /{ }^{238} U$ & ${ }^{236} U /{ }^{238} U$ \\
\hline Mean & 119 & $3.35 \mathrm{E}-04$ & $3.12 \mathrm{E}-02$ & $1.10 \mathrm{E}-04$ & 70 & $3.57 E-04$ & $3.10 \mathrm{E}-02$ & $1.20 \mathrm{E}-04$ \\
\hline
\end{tabular}




\begin{tabular}{lllllll}
\hline -SD (\%) & 16.7 & 6.76 & 26.9 & 22.4 & 7.73 & 37.9 \\
+SD (\%) & 20.1 & 7.25 & 36.9 & 28.9 & 8.37 & 60.9 \\
Relative & & & & & & \\
Difference (\%) & -2.96 & -8.99 & 6.02 & 3.25 & -9.52 & 14.72 \\
-SE (\%) & 1.53 & 0.62 & 2.47 & 2.68 & 0.92 & 4.52 \\
+SE (\%) & 1.84 & 0.66 & 3.38 & 3.46 & 1.00 & 7.28 \\
\hline
\end{tabular}

\section{Discussion}

Sub-micron and micron-sized uranium particles are a challenging sample material for LA-MC-ICP-MS. A possible way forward for ${ }^{235} \mathrm{U} /{ }^{238} \mathrm{U}$ ratio measurements is measuring both isotopes on Faraday detectors ${ }^{22,24,28}$. In doing so three of the limitations imposed by the ion counter are removed: the automatic protection system which deflects away ion beams greater than 2,000 counts per millisecond, the limited dynamic range and now blind time. In our study the data from many of the largest, most valuable, particles had to be rejected due to at least one of these effects. Although the automatic protection could potentially be altered, the limited dynamic range cannot and it would seem for LA-MC-ICP-MS analysis of uranium particles both ${ }^{235} \mathrm{U}$ and ${ }^{238} \mathrm{U}$ should be measured on Faraday detectors. However for small or depleted uranium particles, the resulting small ion beam would be close to the Johnson noise of the $10^{11} \Omega$ amplifier. A recent instrumental development available for MC-ICP-MS, high gain $10^{13} \Omega$ amplifiers, have been applied to the LA-MC-ICP-MS analysis of similar small ion beams ${ }^{54}$, and have been used for uranium isotope ratio analysis by TIMS ${ }^{58}$. Unless TSI data processing is adopted, using high gain amplifiers for LA-MC-ICP-MS of uranium particles does require correcting for the different amplifier tau ${ }^{59}$. Claverie et $a l^{28}$ used the time-shift method developed by Georgiotis et $a l^{51}$ to correct for differences in detector response when analysing 1-3.5 $\mu \mathrm{m}$ uranium particles by LA-MC-ICP-MS. For the population of particles analysed RSD's were $2.1 \%{ }^{235} \mathrm{U} /{ }^{238} \mathrm{U}$ (expected composition $7.248 \times 10^{-3}$ ) and $2.5 \%{ }^{234} \mathrm{U} /{ }^{238} \mathrm{U}$ (expected composition $6.1 \mathrm{x}$ $\left.10^{-5}\right)$. Furthermore by using the time-shift correction they were able to use a point-by-point data reduction strategy to assign an uncertainty to each individual particle. In our study the NUSIMEP-6 population, with a similar isotopic composition, was determined to $\approx 3 \%$ RSD ${ }^{235} \mathrm{U} /{ }^{238} \mathrm{U}$ and $\approx 8 \%$ RSD ${ }^{234} \mathrm{U} /{ }^{238} \mathrm{U}$, for a particle size distribution of $0.64 \pm 0.43 \mu \mathrm{m}$. An RSD of $1.3 \%$ was achieved with the Zircon Cell on SRM 611, for an amount of uranium material equivalent to a $150 \mathrm{~nm}$ uranium particle. The solid glass matrix of SRM 611 was significantly less likely to produce large discrete particulate and hence was less susceptible to blind time.

For mixed detector arrays the results obtained from the ultrafast $\mathrm{DCl}$ suggest the washout time which will give the best signal to noise ratio, without introducing compromising blind time effects, is ca. $0.5 \mathrm{~s}$. As ${ }^{234} \mathrm{U}$ and ${ }^{236} \mathrm{U}$ will still need to be measured on ion counters, using the ultrafast DCl or other rapid washout systems for LAMC-ICP-MS of uranium particles cannot be recommended, unless either the precision and accuracy required is less than the uncertainty due to blind time, or blind time is removed in MC-ICP-MS instrumentation. Such an improvement would be welcome outside uranium particle analysis as currently the efficiency of any analysis with a small integration time is reduced by the multiple blind time events experienced. For an $8 \mathrm{~ms}$ integration 
time $30 \%$ of the introduced ions are currently undetected and ironically, the only time when $100 \%$ of a signal is detected is on an ion counter when the input signal pulse is shorter than the integration time. Even with the $>5 \%$ detection efficiency of the ultrafast laser ablation configuration ${ }^{34}$, the average number of counts of ${ }^{234} \mathrm{U}$ and

${ }^{236} \mathrm{U}$ detected for each sub-micron particle was still too low to reach the precision required by the nuclear safeguards community. For LA-MC-ICP-MS to be a viable tool for minor isotope ratio determination in uranium particle analysis, the particles analysed will either have to be larger, micron sized and above, or be enriched in the minor isotopes.

\section{Conclusion}

Despite significantly improving the signal to noise ratio of the sample introduction set-up for LA-MC-ICP-MS using an ultrafast washout laser ablation cell and torch design, expected improvements in isotope ratio precision were not realized. The highly transient data resulting from the adoption of the ultrafast LA-MC-ICP-MS introduced an additional source of bias and scatter, here termed 'blind time' which recognises a fundamental time limit in some MC-ICP-MS systems where data are not recorded. For highly transient data significant components of time and therefore data can be missed, indicating that accurate determination of such analyses may not be achievable with some MC-ICP-MS instruments equipped with mixed detector arrays. Possible exceptions, such as the ${ }^{234} \mathrm{U} /{ }^{238} \mathrm{U}$ and ${ }^{236} \mathrm{U} /{ }^{238} \mathrm{U}$ compositions investigated in this study, are where counting statistic limitations dominate the uncertainty budget, masking the blind time effects on the isotope ratios. The improvement in signal to noise ratio provided by ultrafast washout laser ablation cell systems was of great benefit in resolving the minor uranium isotopes from the baseline and may yet have a role in future analytical methods if the observed biases and scatter due to blind time could be eliminated. For the Neptune Series MCICP-MS, modelling of blind time suggested a minimum signal duration of $500 \mathrm{~ms}$ is required to eliminate blind time effects when using a mixed detection array. We would therefore recommend that commercially available two-volume cells with washout times of $0.5-1 \mathrm{~s}$ are currently most appropriate to use in conjunction with MCICP-MS instruments for uranium particle analysis. The Zircon Cell (average pulse duration 0.5s) measured an uncertainty of $1.3 \% 1 R S D$ for ${ }^{235} \mathrm{U} /{ }^{238} \mathrm{U}$ for a population of single-shot ablations of SRM 611: the ablated material from each shot was equivalent to a $150 \mathrm{~nm}$ uranium particle. 


\section{References}

(1) Betti, M.; de las Heras, L. A.; Tamborini, G. Appl. Spectrosc. Rev. 2006, 41 (5), 491-514.

(2) May, M.; Abedin-Zadeh, R.; Barr, D.; Carnesale, A. Nuclear Forensics. Role, State of the Art, Program Needs; 2008.

(3) Mayer, K.; Wallenius, M.; Varga, Z. Chem. Rev. 2013, 113 (2), 884-900.

(4) Parrish, R. R.; Horstwood, M.; Arnason, J. G.; Chenery, S.; Brewer, T.; Lloyd, N. S.; Carpenter, D. O. Sci. Total Environ. 2008, 390 (1), 58-68.

(5) Lloyd, N. S.; Chenery, S. R. N.; Parrish, R. R. Sci. Total Environ. 2009, 408 (2), 397-407.

(6) Varga, Z.; Wallenius, M.; Mayer, K. J. Anal. At. Spectrom. 2010, 25 (12), 1958

(7) Stanley, F. E. J. Anal. At. Spectrom. 2012, 27 (11), 1821.

(8) Eppich, G. R.; Williams, R. W.; Gaffney, A. M.; Schorzman, K. C. J. Anal. At. Spectrom. 2013, 28 (5), 666.

(9) Kuhn, E.; Fischer, D.; Ryjinski, M. Enviromental Sampling for IAEA Safeguards: A Five Year Review; 2001.

(10) Pestana, R. C. B.; Sarkis, J. E. S.; Marin, R. C.; Abreu-Junior, C. H.; Carvalho, E. F. U. J. Radioanal. Nucl. Chem. 2013, 298 (1), 621-625.

(11) Witte, T. M. Laser ablation-inductively coupled plasma-mass spectrometry : Examinations of the origins of polyatomic ions and advances in the sampling of particulates by, lowa State, 2011.

(12) Zhang, X. Z.; Esaka, F.; Esaka, K. T.; Magara, M.; Sakurai, S.; Usuda, S.; Watanabe, K. Spectrochim. Acta Part B At. Spectrosc. 2007, 62 (10), 1130-1134.

(13) Shinonaga, T.; Esaka, F.; Magara, M.; Klose, D.; Donohue, D. Spectrochim. Acta Part B At. Spectrosc. 2008, 63 (11), 1324-1328.

(14) Esaka, F.; Magara, M.; Kimura, T. J. Anal. At. Spectrom. 2013, 28 (5), 682.

(15) Esaka, F.; Magara, M.; Lee, C. G.; Sakurai, S.; Usuda, S.; Shinohara, N. Talanta 2009, 78 (1), $290-294$.

(16) Stefánka, Z.; Katona, R.; Varga, Z. J. Anal. At. Spectrom. 2008, 23 (7), 1030.

(17) Lloyd, N. S.; Parrish, R. R.; Horstwood, M.; Chenery, S. R. N. J. Anal. At. Spectrom. 2009, 24 (6), 752758.

(18) Varga, Z. Anal. Chim. Acta 2008, 625 (1), 1-7.

(19) Becker, J. S.; Sela, H.; Dobrowolska, J.; Zoriy, M.; Becker, J. S. Int. J. Mass Spectrom. 2008, 270 (1-2), 17.

(20) Pointurier, F.; Pottin, A.; Hubert, A. Anal. Chem. 2011, 83, 7841-7848.

(21) Pointurier, F.; Hubert, A.; Pottin, A.-C. J. Radioanal. Nucl. Chem. 2012, 296 (2), 609-616.

(22) Kappel, S.; Boulyga, S. F.; Dorta, L.; Günther, D.; Hattendorf, B.; Koffler, D.; Laaha, G.; Leisch, F.; Prohaska, T. Anal. Bioanal. Chem. 2013, 405 (9), 2943-2955.

(23) Ronzani, A.-L.; Pointurier, F.; Rittner, M.; Borovinskaya, O.; Tanner, M.; Hubert, A.; Humbert, A.-C.; Aupiais, J.; Dacheux, N. J. Anal. At. Spectrom. 2018.

(24) Varga, Z.; Krachler, M.; Nicholl, A.; Ernstberger, M.; Wiss, T.; Wallenius, M.; Mayer, K. J. Anal. At. Spectrom. 2018, 33, 1076-1080.

(25) Aregbe, Y.; Truyens, J.; Kips, R.; Richter, S.; Stefaniak, E.; Kühn, H.; Kraiem, M. NUSIMEP-6 : Uranium isotope amount ratios in uranium particles; 2008.

(26) Truyerns, J.; Stefaniak, E.; Mialle, S.; Aregbe, Y. NUSIMEP-7 : Uranium isotope amount ratios in uranium particles; 2011.

(27) Truyens, J.; Stefaniak, E. a; Aregbe, Y. J. Environ. Radioact. 2013, 125, 50-55.

(28) Claverie, F.; Hubert, A.; Berail, S.; Donard, A.; Pointurier, F.; Pécheyran, C. Anal. Chem. 2016, 88 (8), 4375-4382.

(29) Tanner, M.; Günther, D. Anal. Chim. Acta 2009, 633 (1), 19-28. 
(30) Cottle, J. M.; Horstwood, M. S. a.; Parrish, R. R. J. Anal. At. Spectrom. 2009, 24 (10), 1355-1363.

(31) Pettke, T.; Oberli, F.; Audétat, A.; Wiechert, U.; Harris, C. R.; Heinrich, C. a. J. Anal. At. Spectrom. 2011, 26 (3), 475-492.

(32) Allen, L.; Pang, H.; Warren, A. J. Anal. At. Spectrom. 1995, 10 (March), 267-271.

(33) Bleiner, D.; Chen, Z. .

(34) Craig, G.; Managh, A. J.; Stremtan, C.; Lloyd, N. S.; Horstwood, M. S. A. Anal. Chem. 2018, 90 (19), 11564-11571.

(35) Gourgiotis, A.; Manhès, G.; Louvat, P.; Moureau, J.; Gaillardet, J. J. Anal. At. Spectrom. 2015, 30 (7), 1582-1589.

(36) Gourgiotis, A.; Manhès, G.; Louvat, P.; Moureau, J.; Gaillardet, J. Rapid Commun. Mass Spectrom. 2015, 29 (18), 1617-1622.

(37) Krupp, E. M.; Donard, O. F. X. Int. J. Mass Spectrom. 2005, 242 (2-3), 233-242.

(38) Douglas, D. N.; Managh, A. J.; Reid, H. J.; Sharp, B. L. Anal. Chem. 2015, 87 (22), 11285-11294.

(39) Müller, W.; Shelley, M.; Miller, P.; Broude, S. J. Anal. At. Spectrom. 2009, 24 (2), 209-214.

(40) Van Malderen, S. J. M.; Managh, A. J.; Sharp, B. L.; Vanhaecke, F. J. Anal. At. Spectrom. 2016, 31 (2), 423-439.

(41) Wang, H. A. O.; Grolimund, D.; Giesen, C.; Borca, C. N.; Shaw-Stewart, J. R. H.; Bodenmiller, B.; Günther, D. Anal. Chem. 2013, 85 (21), 10107-10116.

(42) Van Malderen, S. J. M.; van Elteren, J. T.; Vanhaecke, F. J. Anal. At. Spectrom. 2015, 30, 119-125.

(43) Horstwood, M. S. A.; Foster, G. L.; Parrish, R. R.; Noble, S. R.; Nowell, G. M. J. Anal. At. Spectrom. 2003, 18 (8), 837-846.

(44) Bleiner, D.; Gunther, D. J. Anal. At. Spectrom. 2001, 16 (5), 449-456.

(45) Douglas, D. N. Development of a High-Speed, High-Efficiency, LA-ICP-MS Interface, Loughborough University, 2013.

(46) Neuhoff, J. Certificate of Analysis CRM 112-A Uranium (normal) Metal Assay and Isotopic Standard; Argonne, 2010.

(47) New Brunswick Laboratory, U. D. of E. Certificate of Analysis CRM U010 Uranium Isotopic Standard (5 mg Uranium as U308); 2008.

(48) Technology, N. I. of S. and. National Institute of Standards \& Technology Certificate of Analysis Standard Reference Material 611; 2012.

(49) Duffin, A. M.; Hart, G. L.; Hanlen, R. C.; Eiden, G. C. J. Radioanal. Nucl. Chem. 2013, 296 (2), 1031-1036.

(50) Dzurko, M.; Foucher, D.; Hintelmann, H. Anal. Bioanal. Chem. 2009, 393 (1), 345-355.

(51) Gourgiotis, A.; Bérail, S.; Louvat, P.; Isnard, H.; Moureau, J.; Nonell, A.; Manhès, G.; Birck, J.-L.; Gaillardet, J.; Pecheyran, C.; Chartier, F.; Donard, O. F. X. J. Anal. At. Spectrom. 2014, 29, 1607-1617.

(52) Hirata, T.; Hayano, Y.; Ohno, T. J. Anal. At. Spectrom. 2003, 18 (10), 1283.

(53) lizuka, T.; Hirata, T. Chem. Geol. 2005, 220 (1-2), 121-137.

(54) Kimura, J.-I.; Chang, Q.; Kanazawa, N.; Sasaki, S.; Vaglarov, B. S. J. Anal. At. Spectrom. 2016, 31 (3), 790-800.

(55) Managh, A. J.; Douglas, D. N.; Makella Cowen, K.; Reid, H. J.; Sharp, B. L. J. Anal. At. Spectrom. 2016, 00, $1-5$.

(56) Lan, K.; Jorgenson, J. W. J. Chromatogr. A 2001, 915, 1-13.

(57) Cottle, J. M.; Kylander-Clark, A. R.; Vrijmoed, J. C. Chem. Geol. 2012, 332-333, 136-147.

(58) Trinquier, A.; Komander, P. J. Radioanal. Nucl. Chem. 2016, 307 (3), 1927-1932.

(59) Craig, G.; Hu, Z.; Lloyd, N. S.; Schwieters, J. . 
